\title{
THE IMPLEMENTATION OF PROPING PROMPTING TECHNIQUES IN STUDENT UNDERSTANDING ON PAI LEARNING MATERIALS IN SMA IT Al-AZHAR BRONDONG LAMONGAN
}

\section{Muhammad Hambal}

e-mail: abu.hana.tsania@gmail.com

\begin{abstract}
A very important element in learning is understanding. Because understanding is an abstraction it can be known from one of them believe by using question and answer. By asking can be known how much student understanding of the lesson. This study aims to find out how the application of probing prompting techniques in the subjects of PAI in SMAIT Al-Azhar Brondong Lamongan? What is the value of students' understanding in the subject matter of PAI at SMAIT Al-Azhar Brondong Lamongan? And how the effectiveness of applying probing prompting technique in students' understanding on PAI subjects at SMAIT Al-Azhar Brondong Lamongan. This type of research is quantitative research, so the results obtained are in the form of numbers from the calculation. Application of probing prompting technique using the mean formula obtained through the observation of teacher ability. As for the effectiveness of applying probing prompting technique in PAI subjects at SMAIT Al-Azhar Brondong Lamongan. Researcher use technique analyze $\mathrm{t}$ test data. The results showed that the application of effective prompting technique in students' understanding on the subjects of PAI in SMAIT AlAzhar Brondong Lamongan.
\end{abstract}

Keywords: Probing Prompting, Understanding and Effectiveness

\section{A. Introduction}

According to the Law of the Republic of Indonesia National mentioned that education is a conscious and planned effort to create an atmosphere of learning and learning process so that learners are actively developing their own 
potential, community, Nation and State. ${ }^{1}$ While Shaykh Mustafa al-Ghulayani explains that Education is calling the noble character in the soul of the students and watering it with guidance and advice. So, it becomes the tendency of the soul that produces virtue. Goodness and love work useful for the homeland.

According Mulyasa, learning is essentially the interaction between learners with the environment so that there is a change in behavior to a better direction. in the learning a lot of factors that affect, both internal and external factors. Teaching and learning is an educational, educational interaction that occurs between teachers and students. Educational value interaction can occur because the learning process is directed to achieve certain goals that have been formulated before the learning is done. The teacher consciously planned his teaching activities systematically by making use of everything for the sake of teaching. ${ }^{2}$

In the learning activities there are two energetic activities that teachers teach and students learn, teachers teach how students should learn. While students learn how to learn through various learning experiences until there is a change in him either from the cognitive, psychomotor and affective aspects with the problem. How to enable students to voluntarily grow awareness of learning? Students will learn actively if the learning plan is arranged by the teacher to require students, either voluntarily or compulsively, to demand the students to do the learning activities.

Learning design that reflects active learning activities needs to be supported by the ability of teachers to facilitate student learning activities during the learning process takes place. Thus, there is a significant correlation between teacher teaching activities and student learning activities. ${ }^{3}$

We realize that teaching is a complex process of activity. Teaching is not as easy as anyone thinks, anyone who has learned, or already read, then he will be able to teach. This is an old presumption that does not want to see how

\footnotetext{
${ }^{1}$ Undang-Undang Republik No. 20 th 2003, Tentang Sistem Pendidikan Nasional (Bandung: Citra Unbara, 2003)

${ }^{2}$ Syaiful Bahri Djamarah, Guru Dan Anak Didik Dalam Interaksi Educatif, (Jakarta: Rineka Cipta. 2005), 77

${ }^{3}$ Marno Idris, Strategi dan Metode Pengajaran
} 
productivity is generated by teachers. A doctor who injected 1000 people, it turns out there are 5 people who died, then this will be a big criminal matter. But a teacher who teaches 40 students in a class, it turns out 15 people fail in his subjects, never questioned in question is his students do not want to learn, of course he failed, This, is the old paradigm. New ideas require that this level of productivity be enhanced and the failure rate of pupils / students to a minimum, with this being enhanced by methods of teaching, evaluation and so on.

Because of the complexity of this teaching process, we must try to improve upon:

1. Before teaching

2. When teaching

3. After teaching

At the time before teaching, the teacher must make preparations, the teacher must know who will be taught. At the time of teaching, teachers should try to learn the theory and practice of teaching, at the time after teaching, the teacher should seek feedback, by asking questions to students or evaluating. In this way, we carry out the following teaching process cycle:

1. Teachers plan

2. Teachers implement

3. The teacher checks. ${ }^{4}$

Tips for optimizing the learning process begin with the improvement of the learning design. However, it should be emphasized that however sophisticated a design of learning is. This is not the only factor that determines the success of learning. But it cannot be denied that the learning process will not work without the design of quality learning.

Hope that is never lost and demanded by the teacher is how the lesson material delivered by the teacher can be mastered the students completely. This is a fairly difficult problem that teachers feel. Difficulties are due to students not only as individuals with all its uniqueness. But they are also social beings with different backgrounds. To create quality students and able to face the times, the need for renewal in the method is a must. The quality of learning can be seen from

\footnotetext{
${ }^{4}$ Bukhari Alma, Guru Profesional.
} 
the process and in terms of results. In terms of learning process is said to be successful and qualified if all or at least most (75\%) learners actively, both physically, mentally and socially in the learning process. In addition to showing the excitement of high learning, great spirit of learning and self-esteem.

While in terms of results, the learning process is said to succeed if there is a positive change of learners entirely or at least most (75\%). An effective and meaningful teaching and learning process will take place if it can provide success for students and teachers themselves.

As an educator, teachers are expected to work professionally, systematically rooted and based on effective and efficient (effective and efficient) methodological didactic principles, meaning teachers can engineer a systematic learning system in the organization of active learning activities. Hence the application of methods greatly influences success in learning. One reason is that the essence of Islamic education lies in its ability to develop the potential of students to become human beings who believe and piety to God.

Giving the method is said exactly when the technique and its application is right. Because the technique is the way it is done in implementing the method. ${ }^{5}$ In the context of teaching, many alternative methods can be chosen by the teacher only the problem how to choose and use methods that can display aspects of process skills. So, a teacher in addition must master the various methods of learning he must also master the techniques and strategies for the methods he has mastered can be applied appropriately in a learning. Because of the importance of a learning for students in their life it becomes important so that the learning process that can run smoothly, effectively and efficiently. teaching and learning activities or other learning is to instill a number of component norms into the psyche of students. All norms are believed to contain goodness that needs to be implanted into the psyche of the learners through the teacher's role in learning. The interaction between teachers and students occurs because of mutual need.

Although in the learning process today the role of pupils is also very dominant, but the teacher remains a determinant of success of a lesson. In fact, teachers often become one of the personal responsible for the success of learning.

\footnotetext{
${ }^{5}$ Sanjaya, Wina, Strategi Pembelajaran, (Jakarta: Kencana, 2006)
} 
Frederick j. Mcdonald says: "The teacher is responsible for the over-all manipulation of the educative act, of the child is the center and focus" (the teacher is the person responsible for all activities of an education in which the center and focus is the children).

From this it is known that the teaching method has a close relationship with process skills in the form of the ability to observe, classify, interpret, predict, apply, plan research, and communicate. The methods we know are: lectures, and frequently asked questions, each of which has a classification of teaching methods relating to different process skills developed.

Questioning methods present five aspects of process skills: observing, classifying, interpreting, applying, communicating. There is no bad method or good method. in other words, we cannot say with certainty that this method is the most effective and the method is the worst, because it is very dependent on various factors. which is important to note the teacher in applying the method is to know the limits of goodness and weaknesses of methods that will be used, allowing it to formulate conclusions about the results assessment / achievement of objectives of the decision. It can be known by the general characteristics, roles and benefits contained in each method that distinguishes between methods one to another.

The methods we know so far between the fabric: lectures, and frequently asked questions, each of which has a classification of teaching methods related to different process skills developed.

In the question and answer method, for example, it presents five aspects of process skill: observing, classifying, interpreting, applying, communicating. And the lecture method presents two process skills: observing, communicating.

From the above classification, it can be seen and it is known that question and answer method have advantages and shows more process skill aspect than the monotonous lecture method, and it only presents two facets of process skill that is observing and communicating and realize therefore lecture method which teachers often use in classroom teaching needs to be limited in their use, process skills developed by lecture methods cannot be expected to optimize student learning in the classroom. ${ }^{6}$ while the question and answer, whether or not realized

\footnotetext{
${ }^{6}$ Guru dan anak didik, 229
} 
in our learning process cannot be separated from the question and answer, whether little or much. ${ }^{7}$ This method has been used for a long time, Socrates said: "If the teacher wants his students to gain a lot of knowledge he should use question and answer". And as a feature of education is the existence of feedback from students and this can be done by giving question and answer.

Feedback given by the students during the course of the course was varied, depending on the stimulus provided by the teacher. The teacher's stimuli vary with varying responses from the learner. Stimulation of teachers in the form of questions, then the response of students in the form of responsibility was born interaction through question and answer between teachers and students. Conversely, the stimulation of students in the form of questions, then the teacher's response in answering as well.

Learning is essentially asking questions and answering questions. Questioning can be viewed as a reflection of every individual's curiosity, while answering questions reflects one's ability to think. It's just that one of the weaknesses of teachers that often happens is impatience to quickly find an answer in accordance with the expectations of teachers, therefore, teachers often answer their own questions raised, so in the end the question has absolutely no meaning to teach students. Therefore, in the process of inquiring, teachers need to provide sufficient opportunities for students to find the right answers. Teachers should avoid to answer the questions themselves. Let students search, guess and explore to find answers according to their ability one of them asks by using the technique "Probing Prompting". Probing Prompting technique is a technique of learning by way of teachers presents a series of questions that are guided and dig so that there is a thought process that links the knowledge of students and experience with new knowledge being studied. A teacher can not necessarily pour something into the minds of students because they themselves must organize what they see and hear into a meaningful unity, without the opportunity to discuss, ask questions, practice then the actual learning process will not happen. ${ }^{8}$ By asking will help students learn with their friends, help students be more perfect in receiving information or

\footnotetext{
${ }^{7}$ Sriyono,dkk, Teknik Belajar Mengajar Dalam CBSA. (Jakarta Rineka Cipta. 1992), 102

${ }^{8}$ Ibid.
} 
can develop high-level cognitive skills. Thus, the teacher will not only learn how to "ask" the good and true, but also learn how the influence of asking in the classroom. ${ }^{9}$

One of the educational units that are so concerned and responsive to the quality of education, especially balancing between the general science and religion of SMA IT Al-Azhar Brondong Lamongan.

Based on the above description, the authors are motivated to conduct a study with the title: The Effectiveness of Implementation Probing Prompting Techniques in Student Understanding on the Lesson Material PAI in SMA IT AlAzhar Brondong Lamongan.

\section{B. Research Methods}

This research is a type of quantitative research with correlational model that is a research that aims to find the presence and absence of a variable with other variables. And if the relationship exists, some of the closeness of that relationship. To find the correlation. So, the authors use statistics in the calculation so that later conclusions obtained can be formulated into data in the form of numbers.

In this research take several steps as follows:

1. Determination of subject and object of research in this subject that is the class VII D and VII E while the object is the understanding of students.

2. Determine the randomized group of experiments and control groups from both classes.

3. Provide Treatment of experimental class with probing prompting technique while PBM in control class is left as usual.

4. Provide post-test to both classes.

To obtain the data then the authors use several techniques, namely:

1. Observation

Observation is a systematic observation and recording of the phenomenon under investigation. ${ }^{10}$ This technique is widely used in both descriptive and

\footnotetext{
${ }^{9}$ Syaiful Bahri Djamarah, Guru Dan Anak Didik Dalam Interaksi Educatif, (Jakarta: Rineka Cipta. 2005), 99

${ }^{10}$ Sutrisno Hadi, Metodologi Research II, (Yogyakarta: fakultas psikologi UGM, 1983) 137
} 
experimental history research, because with these observations research symptoms can be observed closely.

\section{Interview}

Interview is a dialogue conducted by the interviewer to obtain information from the interviewer. ${ }^{11}$ Interviews used here are direct guided free interviews. This means that interviews conducted by respondents answer questions. The interviewer reads the guidelines in the form of an outline of the things to be asked. And become resource person of this interview is principal, teacher of subject of PAI and Head of Administration of SMAIT Al-Azhar Brondong Lamongan. The interview was conducted to obtain data on the general condition of the school, and the learning process of PAI subjects at SMAIT Al-Azhar Brondong Lamongan.

\section{Documentation}

That is the method of collecting data about things in the form of leges, transcripts and so on that are related to the research. This method researchers used to obtain data about the history of the establishment of SMAIT Al-Azhar Brondong Lamongan, school structure, school organization, the number of teachers, employees and students. Documentation is collection through written relics, such as archives and includes books on opinions, theories of theories or laws and others dealing with research problems. ${ }^{12}$

This method the authors use to obtain data from SMAIT Al-Azhar Brondong Lamongan namely:

1) History of its foundation

2) Organizational structure

3) Number of teachers, employees, students

4) Infrastructure

5) Documentation of PAI lesson scores

Data analysis techniques used to analyze the data there are two, namely: 1. Technical analysis of observational data

a. Analysis of teacher ability observation in managing lessons to obtain data about teachers' ability in managing learning using probing prompting technique is

${ }^{11}$ Arikunto, Prosedur, 145

12 S. Margono, Metode Penelitian Pendidikan, (Jakarta: Rineka Cipta, 1997), 181. 
analyzed by calculating the average of every aspect of teacher ability in managing learning during three meetings. The teacher's ability category for each aspect of the learning management is determined by the researcher as follows:

1) The score 4 category is very good

2) The score 3 category good scores

3) The score 2 category is less good

4) The score 1 category score is not good

b. While to provide interpretation of the average final score obtained used the following categories: Category averages guidelines:

\begin{tabular}{|l|l|l|}
\hline No & \multicolumn{1}{|c|}{ Score } & \multicolumn{1}{|c|}{ Category } \\
\hline 1 & $3,25 \mathrm{x} \leq 4,00$ & Very good \\
\hline 2 & $2,50 \mathrm{x} \leq 3,25$ & Good \\
\hline 3 & $1,75 \mathrm{x} \leq 2,50$ & Less good \\
\hline 4 & $1,00 \mathrm{x} \leq 1,75$ & Not good \\
\hline
\end{tabular}

2. The test result analysis

In this analysis will be divided into two:

a. Analysis of students understanding

Data analysis that is used is by counting the mean or range of each control class and experimental class. Then, it is interpreted.

While, to give the interpretation toward the range of students' score used this category:

\begin{tabular}{|c|c|c|}
\hline No & Score & Category \\
\hline 1 & $90-100$ & Excellent \\
\hline 2 & $80 \times \leq 90$ & Very good \\
\hline 3 & $70 \times \leq 80$ & Good \\
\hline 4 & $60 \times \leq 70$ & More than enough \\
\hline 5 & $50 \times \leq 60$ & Almost enough \\
\hline 6 & $40 \times \leq 50$ & Less \\
\hline
\end{tabular}




\begin{tabular}{|c|c|c|}
\hline 7 & $30 \times \leq 40$ & Very less \\
\hline 8 & $20 \times \leq 30$ & Bad \\
\hline 9 & $10 \times \leq 20$ & Very bad \\
\hline
\end{tabular}

b. Effectivity analysis in implementing probing prompting technique

In this research activity, the data needed is quantitative data which is test score. Analysis data which is used is statistical analysis with using $\mathrm{T}$ test.

To know if the score of Fiqih lesson, the students that are given Probing Prompting technique is better or not than score test that is not. So, it is needed to do equality test on both. Otherwise, it is done on normative test and homogenates test in advance.

c. Normality test

Normality test is done to know whether both sample are from population that have normal distribution or not.

The step to test is:

1) Make distribution table on frequency to each data group

2) Counting the range ( $x$ )

explanation:

$$
\begin{aligned}
\bar{X} & =\frac{\sum F_{i} X_{i}}{\sum F_{i}} \\
\mathrm{Xi} & =\text { interval class sign } \\
\mathrm{Fi} & =\text { frequency according to class mark } \mathrm{Xi}
\end{aligned}
$$

3) Counting the main interval (s) from sample class

$$
S^{2}=\frac{n \sum F_{i}\left(X_{i}\right)^{2}-\left(\sum F_{i} X_{i}\right)^{2}}{n(n-1)}
$$

4) Counting frequency table

The step that is done:

a) Stating the minimum range ( $x i$ ) on each class

b) Counting the main score ( $z i)$ to each interval

$$
z_{i}=\frac{x_{i}-\bar{x}}{s} ; \text { for } \mathrm{i}=1,2,3 \ldots \mathrm{n}
$$

\section{Explanation:}


$z i=$ main number

$x i=$ minimum level class $\mathrm{i}$

$x=$ range of score test (from distribution frequency)

$s=$ main interval (from distribution frequency)

c) Calculating the area of each interval class (L)

d) Calculate expected frequency (Ei)

$$
E_{i}=L \times n
$$

Information

$\mathrm{Ei}=$ Expected frequency

$\mathrm{L}=$ the width of each interval class

$\mathrm{n}=$ lots of data

e) Determining the Hypothesis

Ho $=$ The sample is from a normally distributed population

$\mathrm{Ha}=$ the sample comes from a population that is not normally distributed

f) Determining the real level of $\alpha(\alpha=0.05)$

g) Calculating the value of $\lambda 2$ with chi square analysis technique with the formula:

$$
\lambda^{2}=\sum \frac{\left(O_{i}-E_{i}\right)^{2}}{E_{i}}
$$

Information:

$\mathrm{k}=$ number of interval classes

$\mathrm{Oi}=$ frequency of observation

$\mathrm{Ei}=$ expected frequency

h) Looking for value

$$
\lambda^{2}=(l-a)(k-3)
$$

i) Finding test criteria

Ho is accepted if $\chi 2$ counts $<(1-a)(k-3)$ with $\mathrm{dk}=\mathrm{k}-3$

Ho is rejected if $\chi 2$ counts $\geq(1-a)(k-3)$

j) Drawing conclusions

d. Homogeneity Test 
Homogeneity test is done to find out whether the two samples have the same variance or not.

The testing steps are as follows:

1) Determining the hypothesis

Ho $=\mathrm{o} \frac{2}{1}=\mathrm{o} \frac{2}{21}$ samples are from populations that have different variance

Hi: o $\frac{2}{1} \neq=0 \frac{2}{21}$ The sample comes from a population that does not have homogeneous variance

2) Determining the real level $(\alpha=0.01)$

3) Determine the value

$\mathrm{F} \frac{1}{2} \alpha(\mathrm{v} 1 \mathrm{v} 2)$ lists from distribution $\mathrm{F}$ with

$\mathrm{v} 1=$ degrees of freedom of the numerator

$\mathrm{v} 2=$ degrees of freedom denominator

4) Determine the following criteria:

Ho refused if $F_{\text {hitung }} \geq \frac{1}{2} \alpha\left(v_{1} v_{2}\right)$

Ho accepted if $F_{\text {hitung }}<\frac{1}{2} \alpha\left(v_{1} v_{2}\right)$

5) Calculate $F$ with the formula

$$
F_{\text {hitung }}=\frac{\text { varians terbesar }}{\text { varians terkecil }}=\frac{S_{1}{ }^{2}}{S_{2}{ }^{2}}
$$

6) Drawing conclusions

e. Test the similarity of two averages

The two-point equation test is used to compare two different circumstances using t-test. In this study to be built is the difference in student learning outcomes are taught by Probing Prompting Techniques at the end of face to face with student achievement that is not given Probing Prompting Technique. 
1) If both classes are normally distributed with homogeneous variance $(\sigma 1=\sigma 2=\sigma, \sigma$ known $)$ then the test procedure performed is:

2) Determining the hypothesis

Ho = Application of probing prompting technique is not effective in understanding on PAI subjects at SMAIT Al-Azhar Brondong Lamongan.

$\mathrm{Ha}=$ Application of probing prompting technique is effective in understanding on PAI subjects at SMAIT Al-Azhar Brondong Lamongan.

3) Determining the real level of $\alpha(\alpha=0.05)$

4) Calculating the test statistic with the formula

$t_{\text {hitung }}=\frac{\bar{X}_{\text {eskperimen }}-\bar{X}_{\text {kontrol }}}{\sqrt{\frac{S_{\text {eksperimen }}^{2}}{n_{\text {eksperimen }}}+\frac{S_{\text {kontrol }}^{2}}{n_{\text {eksperimen }}}}} \quad$ With $S 2=\frac{\sum\left(x_{1}-\bar{X}\right)^{2}}{n-1}$

Information

$\mathrm{X} 1$ = sample average score 1

$\mathrm{X} 2$ = sample average score 2

$\mathrm{S} 2$ = standard combined deviation

$\mathrm{n} 1=$ number of sample data 1

$\mathrm{n} 2=$ number of sample data 2

1 = sample variance 1

$2=$ sample variance 2

5) Conclusion. ${ }^{13}$

\section{Results and Discussion}

1. Application of Probing Prompting Techniques on PAI Subjects at SMA IT alAzhar Brondong Lamongan

Current curriculum changes from competency-based curriculum at present KTSP have been implemented in all educational institutions deemed capable of implementing

${ }^{13}$ Subana, Drs, Statistik Pendidikan, (Bandung : Pustaka Setia, 2005) 
them, especially in SMAIT Al-Azhar Brondong Lamongan that has been accredited "A" In the teaching-learning process is emphasized is to develop students' competencies that include affective and psychomotor cognitive competence, in other words students are required to be more active towards the learning experience.

According to Mr. Masrukhan, S.Pd., M.Pd.I as Head of SMAIT Al-Azhar Brondong Lamongan this. In the process of teaching and learning. Teachers are always emphasized to be creative and mastered both in mastery of the material and techniques used in a method. It covers all the subjects. Includes PAI subjects.

Schools give the widest possible freedom to the teacher for the good and the achievement of learning goals. In return, teachers also have to report on the performance of the evaluation during good learning.

In addition, according to the mother of Retno Duwiana, S.Pd.I as the teacher of Islamic Religious Education PAI. that in his teaching he always gives different methods at each meeting in order not to make students saturated. But although the different methods are so never left behind is the question both at the beginning and at the end keep giving. Because of the perceived benefits. By giving the study of questions at the beginning. learning can be used as an apperception, reopening the students' memories so that it is easy to connect with the previous material, while giving the questions at the end of the lesson is intended as a temporary evaluation material so that teachers understand everywhere that needs to be reviewed and improved both in terms of methods and strategies, or mastery of the material on the other hand the advantage that students get is that they will be easy and ready in following the next learning because the material has been studied. This cannot be separated from the preparation of a mature teacher who starts from the opening, the core activities until the cover has been well organized so that in the process becomes clear and directed.

Based on observations that have been done there are some things that need to be observed as learning, how to teach later, especially how probling promting techniques in the classroom. Also, as an evaluation for teachers study their own field to fix the part that is still lacking.

There are several aspects to be observed, ranging from written covering preparatory to teaching, among others: RPP, materials to be taught, methods used. 
While in the implementation itself in the classroom, the target of the observation is from the beginning covering how the teacher conditioned the learning space so that the form is conducive and students are ready to start learning, how to say hello and invite students to pray, then how also the ability of teachers in connecting material before giving new material.

Finished observing the initial activities, followed by core activities. Which broadly contains how the teacher classroom so that students not only be the object, but also as the subject of the learning itself. one of which we know is to enable students by dividing into groups in our core activities to see how teachers provide opportunities for students to develop their potential, how students think and learn with peer tutors. And the teacher really becomes a motivator and facilitator in the core activities, even though the teacher is still in control in the learning process. This appears after students learn and discuss with friends and present the results of the discussion, the teacher opens a question and answer opportunity, and it turns out the students are enthusiastic and not shy to ask about the material that is not yet known. Once the students are grasped enough to understand, the teacher explains and conveys the material by linking the results of student discussions.

Less than 25 minutes teachers use the time to review or provide temporary assessments of students' understanding by asking students questions. this is also important for researchers not only to master the class and able to explain the material, it turns out the ability to ask, process a question also needs to be mastered, among others, by simplifying the language in accordance with the ability of students, giving pause to students to think of answers from teacher questions.

When the basic things have been mastered, the teacher starts with (probling) exploring students' understanding more than what the teacher has said. And finally, do not forget the teachers give conclusions from the teaching and learning process they just passed.

2. Analysis Observation ability of teachers in learning subjects PAI in SMA IT alAzhar with Probing Prompting technique

From the research results can be known the average ability of teachers in managing learning subjects PAI with probing prompting techniques for 2 meetings. The 
ability of teachers in preparing for learning is good with an average score of 4 , this is because this technique has been previously applied in the school. in addition, the teacher is also well known to his students. At the second meeting the teachers apply PAI learning subjects with probing prompting techniques well. the preparation is more mature than the previous meetings. This means that the teacher is really ready to apply the learning of PAI subjects by using probing prompting technique, because the teacher is already familiar with the students so it is not awkward anymore in facing it.

Implementation of PAI lesson learning includes introduction, core activities and coverings can be explained as follows. For introduction include conditioned learning room and ready to start lesson, say greetings, convey the purpose of learning, connecting with past lessons, with an average of two meetings is 3.5 which means very good. this is because the teacher is clear in the delivery of learning objectives and activities are expected so that students are easy to understand the expected objectives and learning activities, in addition, before starting the teacher's learning always review the material that has been studied in each meeting.

The core learning activities during the two teacher meetings get an average of 3.6 which means very well because in the process, the teacher activates the students by dividing the class into several groups. in addition, because the teaching teacher is in accordance with the lesson plan and learning objectives, so students understand the material presented by the teacher. In each of these two meetings the teacher can greatly manage the average grade lesson ' 4 '.

Before closing the lesson in each meeting the teacher always concludes the learning outcomes and gives both prompting and probing questions to the students and the average score is 3.7 which means very good. this is because also in the process of question and answer teachers always motivate students.

For the teacher's ability to manage time, the teacher is good at every meeting with a mean value of 3 which means good. this is because at every meeting of teachers in managing learning is in accordance with the RPP (Learning Implementation Plan) and teachers are also able to manage the class and enthusiasm of students is still very good. its average rating of 3 is good.

\section{Analysis of the effectiveness of the application of probing prompting technique}


Based on the results of this study, Ho proposed that students 'understanding by using probing prompting technique $=$ students' understanding by not using probing prompting technique is rejected. And Ha which states that students' understanding with probing prompting technique $\neq$ understanding of students by not using probing prompting technique accepted. It can be concluded that the technique of probing prompting is more effective in understanding students in PAI subjects in SMAIT Al-Azhar Brondong Lamongan.

\section{Conclusions}

Based on the results of research that has been described then it can be concluded that: (1) Application of probing prompting method in learning PAI in SMAIT Al-Azhar Brondong Lamongan very good; (2) The value of students' understanding by not using probing prompting technique on the subjects of al-Islam is more than enough in SMAIT Al-Azhar Brondong Lamongan. While the value of students' understanding using probing prompting technique on the subjects of al-Islam is good in SMAIT Al-Azhar Brondong Lamongan; (3) The technique of probing prompting is effective in understanding students in PAI subjects at SMAIT Al-Azhar Brondong Lamongan.

For the sake of progress and improvement in the field of education, the suggestions that researchers can provide are as follows:

1. Teachers as educators who directly interact with students in the learning process, teaching, are expected to continually enrich themselves with knowledge of various strategies and learning methods that have an important role in the learning process. 2. Should be further enhanced in the skills to ask questions in the classroom so as to familiarize the students to hone and dig deeper understanding and improve students' ability in issuing opinions.

3. In the process of teaching and learning, teachers should prioritize student activeness. Therefore, teachers in addition to choosing methods also learn the techniques of implementation, to fit the desired results.

\section{References}


Undang-Undang Republik No. 20 th 2003, Tentang Sistem Pendidikan Nasional, Bandung: Citra Unbara, 2003.

Syaiful Bahri Djamarah, Guru Dan Anak Didik Dalam Interaksi Edukatif, Jakarta: Rineka Cipta. 2005.

Ismail, Strategi Pembelajaran Agama Islam Berbasis PAIKEM, Semarang Rosail Media Group. 2008.

Marno Idris, Strategi dan Metode Pengajaran, Yogyakarta: Arus Media, 2008.

Bukhari Alma, Guru Profesional, Bandung: Alfabetta. 2009.

Sanjaya, Wina, Strategi Pembelajaran, Jakarta: Kencana, 2006.

Sriyono,dkk, Teknik Belajar Mengajar Dalam CBSA, Jakarta Rineka Cipta. 1992.

Bidang Akademik UIN Sunan Kalijaga. Konsep Edutaiment Dalam Pendidikan Islam. Yogyakarta. 2008.

WJS, Poerwadarminta, Kamus Umum Bahasa Indonesia, Jakarta: Balai Pustaka, 1993.

Depdikbud, Kamus Bahasa Umum Indonesia, Jakarta: Balai Pustaka, tt

Nasution. Metode Reseach, Jakarta : Bumi Aksara.

Silbermanm Melvin L, Active Learning, Yogyakarta: Pustaka Insani Madani, 1996.

Suharsimi Aritmoko, Prosedur Penelitian Suatu Pendekatan Praktek, Jakarta: Rineka Cipta 2002.

L.B, Netra, Statistik Inferensional, Surabaya: Usaha Nasional, 1974

Suyatno. Menjelajahi Pembelajaran Inovatif, Sidoarjo: Mass Media Buana Pustaka, 2009.

J. Murshell dan S. Nasution, Mengajar Dengan Sukses Bandung: Jemmars, 1994

Nana Sudjana, Cara Belajar Siswa Aktif, Bandung: Remaja Rosdakarya. 1995.

Dimyati dan Mudjiono, Belajar dan Pembelajaran, Jakarta: PT. Rineka Cipta, 1999

Nana Sudjana, Penilaian Hasil Proses Belajar Mengajar, Bandung: PT. Remaja Rosda Karya, 1995.

Nana Syaodih Sukmadinata, Landasan Psikologi Proses Pendidikan Bandung: PT. Remaja Rosdakarya, 2005.

Syaiful Bahri Djamarah dan Azwan Zain, Strategi Belajar Mengejar, PT. Rineka Cipta: Jakarta, 2006.

Suharsimi Arikunto, Dasar-Dasar Evaluasi Pendidikan, Jakarta: Rineka Cipta. 2002.

Nana Sudjana, Dasar-Dasar Proses Belajar Mengajar, Bandung: PT. Sinar Baru Algesindo, 1995.

Uzer Usman, Lilis Setiawati, Upaya Optimalisasi Kegiatan Belajar Mengajar, PT, Remaja Rosdakarya: Bandung, 1993

Mustaqim, Abdul Wahab, Psikologi Pendidikan PT. Rineka Cipta, Jakarta, 1996. 
Oemar Hamalik, Kurikulum dan Pembelajaran Bumi Aksara: Jakarta, 1995.

Abu Ahmadi dan Widodo Supriyono, Psikologi Belajar. Jakarta: Rineka Cipta. 2003

De Bono, Pelajaran Berfikir Jakarta: Erlangga, 1990,

Suharsimi Arikunto, Prosedur Penelitian Suatu Pendekatan Praktis, Edisi Revisi V, Jakarta: Rineka Cipta, 1997.

Sumadi Surya Brata, Metodologi Penelitian, Jakarta: Raja Grafindo Persada, 2004.

Sutrisno Hadi, Metodologi Research II, Yogyakarta: fakultas psikologi UGM, 1983

S. Margono, Metode Penelitian Pendidikan, Jakarta: Rineka Cipta, 1997. Subana, Drs, Statistik Pendidikan, Bandung : Pustaka Setia, 2005. 